\title{
Isolation of Pseudomonas cepacia D-202: an Available Biocontrol Agent to the Storage Rot of Sugar Beet
}

\author{
Shu ISHIKURI*, Hirokatsu UCHINO* and Katsuichi KANZAWA* \\ Key words : biological control, storage rot, sugar beet, Botrytis cinerea, Penicillium \\ expansum, Pseudomonas cepacia.
}

In Japan, sugar beet (Beta vulgaris L.) is cultivated only in Hokkaido. The total area for cultivating the sugar beets is about 72,000 ha and the total amount of the harvest is about 3.9 billion kg. The roots of sugar beet are harvested between middle October and early November. About two third of the crop are stored outdoors in piles covered with plastic sheets. And some of them are stored up to late March to await processing.

During the storage period, the reduction of the sugar content of roots occurs partly by the normal respiration of beet roots but mainly by the storage rot $^{1,2)}$. The disease is caused mainly by Botrytis cinerea and/or Penicillium expansum in Japan ${ }^{3}$. However the prevention of the disease during the storage period is an important problem, the application of chemical fungicide to harvested crops is illegal in Japan, and also the tolerant varieties are not registered. Therefore we manage to keep the temperature of the storage piles between 4 and $6^{\circ} \mathrm{C}$ in order to prevent the disease. For a relatively short storage period, this method works well, but with the lapse of storage period especially after middle January, the occurrence of storage rot is often observed.

As a new method for preventing the storage rot of beet roots, we investigated the biological control of the pathogens. In this paper, we report the isolation process and antifungal activities of the bacterium against B. cinerea and P. expansum; which was identified as Pseudomonas cepacia.

Isolation of bacteria from soils. We collected 133 soil samples from fields of various crops around Obihiro city in November 1987. For the isolation of bacteria, we applied egg albumin and DNB (100-fold diluted nutrient broth $)^{4}$ agar media. For the assay of the antifungal activities of the bacteria, we used two fungi, $B$. cinerea (58-SR-105) and P. expansum (57-SR-61) as indices; both of them were isolated from rotted beet roots ${ }^{3}$. The spores of $B$. cinerea and $P$. expansum were collected from the two weeks old plate culture on Clark's medium ${ }^{5)}$ and potato-dextrose agar, respectively.

After suitable dilutions with distilled water, the soil suspension was inoculated to 10 agar plates for each medium. The plates were incubated for two weeks at $27^{\circ} \mathrm{C}$. Spore suspension $\left(10^{5}\right.$ conidia $\left./ \mathrm{ml}\right)$ of $B$. cinerea was sprayed onto respective five of them, $P$. expansum $\left(10^{5}\right.$ conidia $\left./ \mathrm{ml}\right)$ was also sprayed onto respective five plates. Plates were incubated for three days at $27^{\circ} \mathrm{C}$. After incubation, the bacteria which showed inhibition zone against $B$. cinerea or $P$. expansum were picked up and maintained on egg albumin or DNB agar slants.

We obtained 3,013 isolates of antifungal bacteria; 1,526 isolates were obtained from plates sprayed with the spores of $B$. cinerea, and 1,487 isolates were obtained from that of $P$. expansum.

Isolation of bacteria from beet roots. We collected beet roots from six storage yards around Obihiro city in January 1988. For each yard, we collected two of the healthy roots and that of rotted ones. In the case of healthy roots, the soil on the roots containing the peridermal tissues was dispersed by the blender and plated. And in the other case, in addition the same method, rotted tissue was also plated. The media applied, and incubation conditions were the same as soil samples.

* Research Center, Nippon Beet Sugar Mfg. Co., Ltd., Obihiro, Hokkaido 080, Japan 研究所 
We obtained 101 isolates of antifungal bacteria; 55 isolates were obtained against $B$. cinerea, and 46 isolates were obtained against $P$. expansum.

Preliminary screenings. First screening was carried out on the agar medium as follows. All bacterial isolates were cultured in the peptone-yeast extract liquid medium (peptone $0.5 \%$, yeast extract $0.3 \%$, nutrient extract $0.3 \%$, glucose $1.0 \%, \mathrm{pH} 7.0-7.2)$ for five days at $25^{\circ} \mathrm{C}$. Forty $\mu 1$ of cultural suspension was applied to the paper disk $(8 \mathrm{~mm}$ in diameter $)$ and the paper disk was put on the center of potato-dextrose agar plate. For each isolate, we prepared two plates and sprayed the spores of $B$. cinerea and $P$. expansum, respectively. Plates were incubated for three days at $25^{\circ} \mathrm{C}$, and the area of inhibition zone was measured. We repeated this experiment for four times and selected 61 isolates; 27 isolates inhibited the growth of $B$. cinerea, and 34 isolates inhibited B. cinerea and P. expansum.

Second screening was carried out on the pieces of beet roots. For each isolate, we prepared two pieces of beet roots $(5 \mathrm{~cm}$ square with $1 \mathrm{~cm}$ thick). On the surface of the piece of beet roots, $0.8 \mathrm{ml}$ of bacterial suspension was applied. We gave the bruise to make depression on the center of piece and applied $40 \mu 1$ of spore suspension $\left(10^{7}\right.$ conidia $\left./ \mathrm{ml}\right)$ of $B$. cinerea and that of $P$. expansum, respectively. These pieces were kept in the petri dishes and incubated for two weeks at $8^{\circ} \mathrm{C}$. By this experiment we selected 18 isolates; all of them inhibited the growth of B. cinerea and P. expansum.

Screenings on beet roots. The storage rot of beet roots was reported to occur by the natural infection from bruised tissue during the storage period at outdoors in piles ${ }^{1,6}$. To make a similar experimental condition, we used split or bruised beet roots.

Third screening was carried out with the sections of beet roots split in four. For each isolate, we prepared five sections and applied about $5 \mathrm{ml}$ of bacterial suspension to each section by dipping. These sections were stored in the plastic bag to keep wet and stored for two months at $8^{\circ} \mathrm{C}$. By this experiment we selected five isolates (D-19.2, D-189.2, D-193.1, D-197.2 and D-202) which showed the successful reduction of storage rot. These are the isolates from non-rhizosphere soil with DNB medium.

Final screening was carried out with the whole beet roots which were bruised by the same mechanism of soil separator of beet harvester. For each isolate, we prepared 120 bruised beet roots (cv. Monoace). And we applied about $20 \mathrm{ml}$ of bacterial suspension to each beet root by dipping. These beet roots were kept in the plastic bag to keep wet and stored for 105 days at $8^{\circ} \mathrm{C}$. Compared with the stored beet roots without bacterial application, all the five isolates showed successful reduction of storage rot (Table 1 and Plate I). Among them, the most effective isolate D-202 was selected, which was obtained from a field cultivated sugar beets.

Identification of bacterium. The isolate D-202 was clasified according to Palleroni ${ }^{7)}$. Table 2 shows the morphological and biochemical characteristics of the isolate and Pseudomonas cepacia IFO-14595. As shown in Table 2, the isolate showed almost the same characteristics to Pseudomonas cepacia IFO-14595 and was identified as Pseudomonas cepacia with the following results; Gram-negative

Table 1. Effect of the antifungal bacteria on the control of storage rot of beet roots

\begin{tabular}{lcc}
\hline \hline \multirow{2}{*}{ Isolates } & \multicolumn{2}{c}{ Storage Rot } \\
\cline { 2 - 3 } & Average Index $^{\text {a })}$ & Occurrence Ratio $^{\text {b) }}(\%)$ \\
\hline D-19.2 & 0.26 & 23.3 \\
D-189.2 & 0.23 & 21.7 \\
D-193.1 & 0.24 & 23.3 \\
D-197.2 & 0.19 & 25.0 \\
D-202 & 0.13 & 13.3 \\
Control $^{\text {c) }}$ & 0.50 & 41.7 \\
\hline
\end{tabular}

a) Average Index $=\frac{\text { Sum of the indices of each beet root }}{\text { Total number of beet roots }}$, where the indices of storage rot are defined as follows; 0 : No symptom was observed.

1, 2, 3, 4 and 5: About 10, 30, 50, 80 and 100\% volume of beet roots were rotted, respectively.

b) Occurrence ratio $=\frac{\text { Number of rotted beet roots }}{\text { Total number of beet roots }} \times 100(\%)$.

c) Beet roots without bacterial application. 
Table 2. Morphological and biochemical characteristics of the isolate

\begin{tabular}{|c|c|c|}
\hline Characteristics & D-202 & IFO- $14595^{\mathrm{a}}$ \\
\hline Cell shape & Short rods & Short rods \\
\hline Cell diameter, $\mu \mathrm{m}$ & $0.7-1.1$ & $0.7-1.0$ \\
\hline Cell length, $\mu \mathrm{m}$ & $1.7-3.1$ & $1.4-2.3$ \\
\hline Gram stain & - & - \\
\hline Motility & + & + \\
\hline Flagella & Polar $>1$ & Polar $>1$ \\
\hline PHB accumulation & + & + \\
\hline Arginin dihydrolase & - & - \\
\hline Catalase reaction & + & + \\
\hline Denitrification & - & - \\
\hline Gerlatin liquefaction & + & + \\
\hline $\mathrm{H}_{2} \mathrm{~S}$ production & - & - \\
\hline Indole production & - & - \\
\hline Lysin decarboxylase & + & + \\
\hline Nitrate reduction & + & - \\
\hline OF-test & Oxidative & Oxidative \\
\hline Ornithine decarboxylase & + & + \\
\hline Oxidase reaction & + & + \\
\hline Vogel-Proskauer & - & - \\
\hline Urease & + & + \\
\hline $\begin{array}{l}\text { Utilization of: Arabinose, 2,3- } \\
\text { Butylene glycol, Citrate, Glucose, } \\
\text { Fructose, Malate, Mannitol, Sucrose, } \\
\text { Xylose, Levulinate }\end{array}$ & + & + \\
\hline Adonitol, Inositol, Rhamnose & - & - \\
\hline
\end{tabular}

a) IFO-14595: Pseudomonas cepacia.

aerobic rod, motile by several polar flagella, Oxidase-positive, Catalase-positive, Oxdative OF test, PHB is accumulated as carbon reserve material, Arginine dihydrolase present, utilization of levulinate and 2, 3-Butylen glycol.

This strain, Pseudomonas cepacia D-202, has been deposited in the Fermentation Research Institute, Agency of Industrial Science and Technology Japan, under the accession number FERMP-11559.

The inhibition mechanisms of $P$. cepacia D-202 against $B$. cinerea and $P$. expansum are now under investigation.

\section{Literature cited}

1. Bugbee, W.M. (1986). In Compendium of Beet Diseases and Insects (Whitney, E.D. et al. eds.). APS Press, St. Paul. pp. 37-39.

2. Ui, T. (1960). The important diseases of sugar beets in Japan and their researches (in Japanese). Tensaikenkyukai-kenkyuhoukoku $2: 24-90$.

3. Uchino, H. and Kanzawa, K. (1984). Studies on the storage rot of sugar beets 1. Fungi isolated from stored sugar beets and their pathogenicity. Proc. Sugar Beet Res. Assoc., Japan 26: 180-189.

4. Hattori, T. (1976). Plate count of bacteria on soil on a diluted nutrient broth as a culture medium. Rep. Inst. Agric. Res. Tohoku Univ. $27: 23-30$.

5. Clark, C.A. and Lorbeer, J.W. (1977). Comparative nutrient dependency of Botrytis squamosa and B. cinerea for germination of conidia and pathogenicity on onion leaves. Phytopathology $67: 212-218$.

6. Hull, R. (1960). Sugar Beet Diseases Bulletin No. 142. Her Majesty's Stationary Office, London. pp. 48.

7. Palleroni, N.J. (1984). In Bergey's manual of systematic bacteriology. Vol.1 (Krieg, N.R. et al. eds.). Williams \& Wilkins, Baltimore. pp. 140-199. 


\section{和 文 摘 要}

石栗 秀・内野浩克・神沢克一：テンサイ貯蔵腐敗病の微生物防除：実用株 Pseudomonas cepacia D-202 の分離

テンサイ貯蔵腐敗病を拮抗微生物を用いて防除するために，土壊および貯蔵中のテンサイ根から主たる病原菌であ るBotrytis cinerea および Penicillium expansum に拮抗作用を示す細菌を 3,114 株分離した。寒天平板並びにテンサ イ根を用いて，これらの病原菌の生育を最も強く抑えた 1 株(D-202) を選択した。本菌株による貯蔵腐敗病の低下は, テンサイ個体を用いた実験により確認された。本菌株について細菌学的な検討を行ったところ, Pseudomonas cepacia と同定された。

(Received August 12, 1991) 


\section{Plate I}
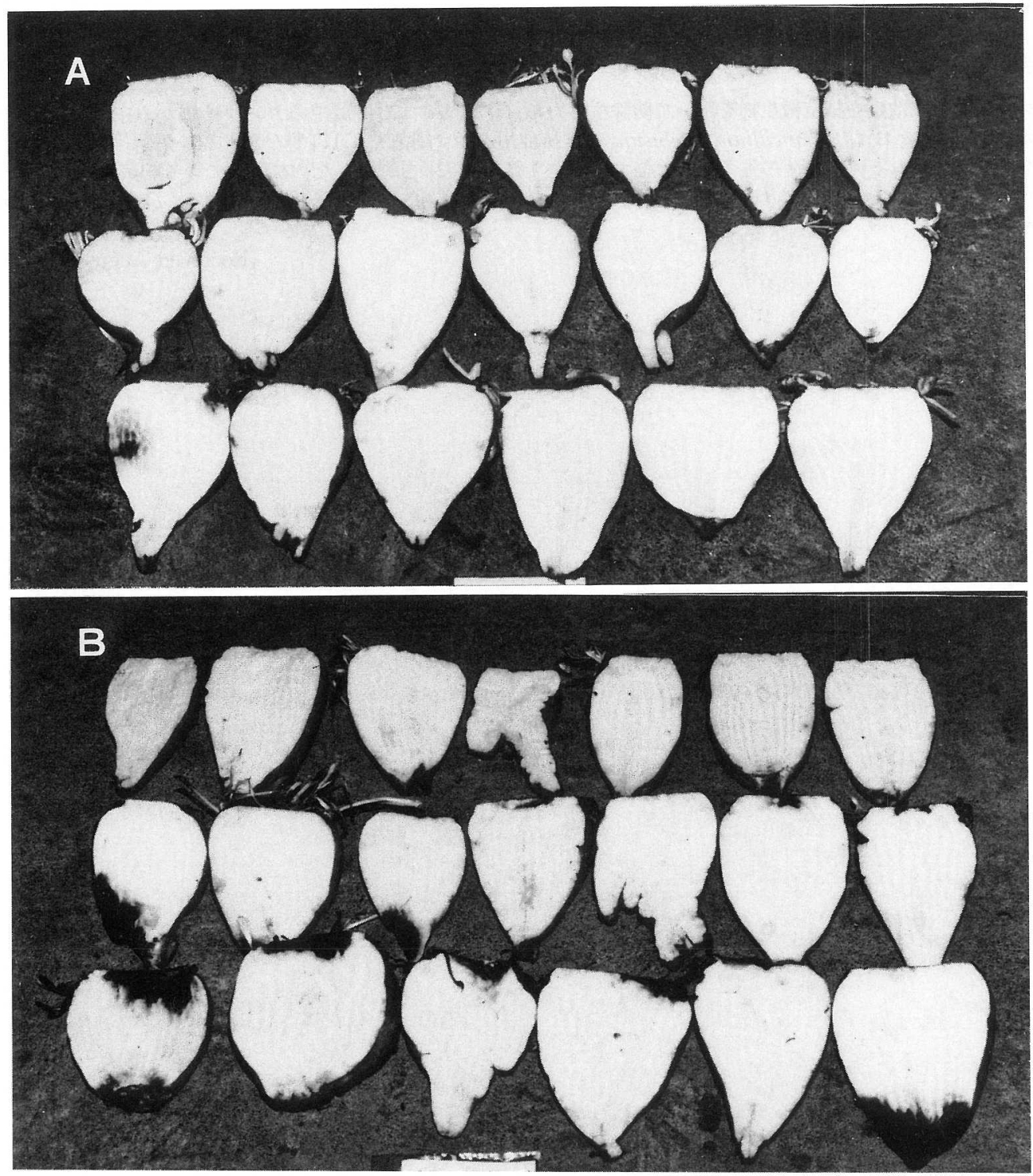

Biological control of storage rot of sugar beets by $P$. cepacia D-202.

A: The roots applied by $P$. cepacia D-202,

B: Storage rot on beet roots without bacterial application. Dark brown rotted tissues were observed. 